Man and Nature

L'homme et la nature

\title{
Liberation from Tutelage? A Sketch of Women's Education in 18th Century Germany
}

\section{Christa Fell}

Volume 7, 1988

URI : https://id.erudit.org/iderudit/1011924ar

DOI : https://doi.org/10.7202/1011924ar

Aller au sommaire du numéro

Éditeur(s)

Canadian Society for Eighteenth-Century Studies / Société canadienne d'étude du dix-huitième siècle

ISSN

0824-3298 (imprimé)

1927-8810 (numérique)

Découvrir la revue

Citer cet article

Fell, C. (1988). Liberation from Tutelage? A Sketch of Women's Education in 18th Century Germany. Man and Nature / L'homme et la nature, 7, 13-21. https://doi.org/10.7202/1011924ar

Copyright (c) Canadian Society for Eighteenth-Century Studies / Sociéte canadienne d'étude du dix-huitième siècle, 1988
Ce document est protégé par la loi sur le droit d'auteur. L'utilisation des services d'Érudit (y compris la reproduction) est assujettie à sa politique d'utilisation que vous pouvez consulter en ligne.

https://apropos.erudit.org/fr/usagers/politique-dutilisation/ 


\section{Liberation from Tutelage? A Sketch of Women's Education in 18th Century Germany}

Eighteenth-century Germany with its many enlightened endeavours was, at the same time, not a place where enlightened men tolerated emancipated women. ${ }^{1}$ Maintaining the popular notion of women, and especially women's education, Germany remained a conservative enclave. Its women did not play as visible a public role as they were beginning to do in other countries.

Girls' education on a broad social basis did not exist until Luther's time. He, logically and consistently, included girls in his proposals. The school ordinances which followed should have resulted in institutionalized education for boys and girls, at least in the towns. However, this did not materialize until the end of the eighteenth century, when it came about as a consequence of the period of reform which followed the French revolution. Before then, girls' schools were on noone's list of priorities. Some of the reasons were inherent in the direction of Luther's reform proposals which put the financial burden for schools on worldly authorities. Other reasons found their origin in a long-standing tradition representing hard reality which still dictated social conditions and the status of women around 1700 . The popular image of the woman was: a 'weak creature' with a 'pliable heart,' who could be 'brought into rage with one word.' ${ }^{2}$ The ideal woman was one who had learned to channel these natural propensities as the result of strict and proper upbringing ('Zucht'), and who had become submissive, silent, industrious, modest, pious, and charitable: typical gender characteristics which dominated the social scene for centuries. This generalized portrayal of an allegedly emotional, weak and therefore inferior being led to a different treatment of boys and girls in the child-rearing process. Childhood was considered a period in which potential ill-effects could be alleviated and suitable virtues instilled. Girlhood was a jealously protected and guarded stage. Girls were the focus of greater concern because of the underlying belief that they were by nature less able and less willing to withstand temptations of the 
flesh and less eager to listen to reason. ${ }^{3}$ In addition, a girl had an inborn quality that had to be guarded: her chastity. The centrality of this natural attribute is reflected in Vives's words: 'If this is lost, it will not be regained. ${ }^{\prime 4} \mathrm{~A}$ rigorous method in the child-rearing process was not only desirable but obligatory if the goal was to be attained. A girl had to be protected from her own dangerous tendencies as well as from those dangers that surrounded her. These ideas caused in all parties involved feelings of anxiety, and put severe restrictions on her, and on women in general. A girl was not allowed to travel by herself; even a married woman was confined in her place. The 'Bildungsreise' which was considered the final stage and conclusion of a young man's education, and which would have widened her horizon was an impossible thought for a young woman. Symptomatic of the compromised female existence is the story of the monk from St. Affrae at Meissen who is said to have proclaimed each time he baptized a girl: 'Now that you are baptized, drown right away. ${ }^{\prime 5}$ The spurious assertion that women were without souls was often repeated and earnestly argued against. ${ }^{6}$ The fact that these two items found mention in a publication of 1700, 'Die neue böse Post,' showed that under given social conditions women were still considered low and despicable creatures. Even if the author characterized this misogynist attitude as 'satanic,' the historical mask lends itself to a comparative method in which he subjected his own society to a severe critique.

In the design of strict and proper upbringing two important tasks had to be borne in mind.

1 If we believe that women are human beings they, like all human beings, would have to be saved.

2 Those women-to-be would have to be prepared for their pivotal roles in the Christian economy as spouses, household managers and mothers.

This meant that child-rearing was as much of religious as social importance. A combination of correction and protection was bound to be reflected in the child-rearing measures which were recommended for girls. There was the implicit assumption that increased knowledge in the faith and protection against evil influences would make them better behaved women. However, one should bear in mind that human nature seems to be such that protection often camouflages dominance.

Only a small percentage of the female population received an elementary education, with a high concentration in certain places and social classes. Girls went to German, not to Latin schools, which were ex- 
clusively designed for boys. The increasing insistence on the separation of the sexes meant that girls were taught separately and not altogether equally. They were often instructed by the teacher's wife, who usually was not properly trained to provide the appropriate instruction. Furthermore, these German schools were vulnerable to fluctuating economic and political conditions, since Luther had put the responsibility for education squarely upon city and state governments. Even if those in power were convinced that a sound educational system would be beneficial to the affairs of church and state, they were often unconvinced that such a system should include girls. It was therefore cheaper to leave the education of girls in the hands of private teachers and home tutors who were dependent for their incomes on tight-fisted parents who were satisfied with the minimal when it came to the education of daughters.

The foregoing characterized the social atmosphere around 1700, in a society in which, for example, the merchants in Augsburg and Nuremberg excluded their daughters from the parlour when male visitors arrived. The custom was practiced that women had to keep quiet when men were talking. ${ }^{7}$ It was a time when witchhunts and the demonization of the woman by no means were matters of the past, and the majority accepted the inferiority of the woman and her subordination to man as natural and as in accordance with God's will. In 1693, Ludwig von Seckendorff lamented bitterly, in his Christian State, the irresponsibility with which girls' education was neglected. ${ }^{8}$

The Enlightenment desire for education had some impact on women's education since there were obvious gaps that had to be filled. The role of women and gender relations were central concerns of the educational theorists of the eighteenth century. The debate of the subject itself indirectly testified to the novelty and urgency of the problem. Though actual gains were modest, the eighteenth century witnessed some noteworthy developments in this area. Public opinion was nudged towards a greater awareness of women's social and educational handicaps, although public morality maintained the ideal of the chaste and devoted housewife. Even at the close of the century no radical break with these traditional concepts was in evidence. When in 1755 the University of Halle awarded the first doctorate to a woman it was a milestone in history. ${ }^{9} \mathrm{~A}$ woman had attained recognition as a physician and achieved a position in society which required a thorough education, equal to that of men. It would be wrong to conclude from this evidence that the German woman from now on could enjoy her independence and the freedom to develop her intellectual abilities. Basically, educational equality remained an abstract ideal at a great distance from a social reality which was informed by thinking patterns of 
centuries past. It was also shaped by men's political and social dominance in spite of the tendencies of pietism and enlightenment which were in general favourably disposed to an improvement of women's education. To make women's education the focus of discussion was not a luxury of the time but a necessity in a changing society. However, this did not free women from traditional social attitudes and conditions. They were still considered immature, dependent, uneducated; and the few individuals who had the courage to flout convention and who tried to transcend the deplorable state of their existence were only a handful and considered to be outsiders. Men played the dominant role in family, society, politics and religion. The moral demand for selfless love, devotion and sacrifice was encountered in the idea of feminity as the crown of nature, and housework was considered a woman's natural task. This put massive intellectual limitations on her. Her status was hence geared to a receptive form of existence.

Educational theory in the eighteenth century, especially with regard to girls' secondary education, was strongly characterized by influences from abroad. In 1698, the pietist August Hermann Francke translated Fénelon's 'Traité sur l'éducation des filles' which influenced his plan of the 'Gynaeceum,' a boarding school for the daughters of the upper classes, the first one of its kind in Germany. Francke, who had been such a successful paedagogue/entrepreneur in establishing schools for all classes and both sexes, failed in this endeavour. This failure was indicative of society's skeptical attitude towards secondary, not to speak of post-secondary, education for girls.

However, the growing number of journals directed to a female audience in the $1720 \mathrm{~s}$ and $30 \mathrm{~s}$ indicated an increased literacy among women. Based on their English models, the German 'Moral Weeklies' - of which about 500 existed at that time - offered a platform for discussing feminine problems among which pedagogical issues were of immense concern. The journals were remarkably free from conventional views of womanhood. The liberal ideas of English philosophy granted women a higher degree of self-awareness and individuality, and encouraged them to seek a life of happiness and peace for mankind. Back in 1673, the question was discussed whether the female sex was by nature equal in intellect to man and as capable and fit to perform virtuous deeds. After long-winded consideration of the argument, ${ }^{10}$ the answer was 'yes,' though in 1715 Georg Christian Lehms regretted that these outrageous old notions were still very much alive. ${ }^{11}$ The 'Moral Weeklies' finally accepted the intellectual equality of the sexes. The 'Patriot' and the 'Vernünftigen Tadlerinnen' were chockful of feminine insights. They invited active participation of their female readers by soliciting articles from them. This opened new educational 
possibilities and eventually also new careers. The 'Patriot' suggested a detailed plan for a 'Daughters' Academy' which was directed to an upper-class bourgeoisie, not necessarily rich, and in which faint traces of a challenge to traditionalism could be noted..$^{12}$ They recommended, for example, the employment of female teachers. The educational objectives, however, were a solid education in proper domestic management.

An improved women's education as an antidote to general demoralization was propagated. Contemporaries tended to interpret the social problem of moral decay as a result of the negligence with which women's education was treated. Indeed, their preoccupation with luxury, excess, idleness and immorality was rife through these years. The need for education as a form of social control was a dominant theme. It seemed a sound argument - from a male viewpoint - that the general corruption of society should be blamed on the slovenly education of women. To make them competent wives, house mistresses and mothers who would regard the education of their children as a natural task and not place it in the hands of servants, governesses and 'home tutors' was the overall aim. Improvements were to lead to a regeneration of social morale. Learned academies, not only in Germany, occupied themselves with the unfortunate situation. The prize question of the academy at Besançon in 1747 was: 'In which way could the education of women contribute to improve mankind?' Education was also thought to counteract innumerable unhappy marriages. Women were charged in this respect with a practically impossible task of functioning as correctives in society. There was no improvement in women's education which would provide a better opportunity to develop as human beings. However, in the long run it provided them with more and better schools, thus indirectly building up an improved status which helped to bring about a less constrained view of them in the Age of Romanticism.

Sometimes plans were so idealistic that they could hardly be put into practice immediately. Gottsched, a progressive thinker, acknowledged women to be gifted intellectually: he thought they could be trained far beyond their usual vocations as spouses, household managers and mothers. Since to him knowledge was the source of virtue, he advocated equal education for the sexes: girls, that is, mothers-to-be, could be just as harmful or useful to the state as boys. Above all, they were the first educators of the new generation. ${ }^{13}$ In fulfillment of this crucial task, their knowledge must go beyond the basics and include logic, ethics, metaphysics, physics, history, geography, and - last but not least - religion, which in the course of the century assumed more and more a secondary role. He proposed their admission to all learned 
professions, including academic ones, especially medicine. They also should be made capable of teaching their own sex. He even suggested a university chair in domestic management. The 'Gottschedin' did not look through rosy glasses as did her husband. Although she demanded equal educational opportunities for women, she could not accept the idea that knowledge alone would make a perfect woman unless she devoted herself to other feminine skills. ${ }^{14}$ It was quite common, even among pedagogical theorists, to reject genuinely learned women, while accepting clever women. After all, 'the wise woman does not parade her knowledge.' She had to hide it and appear unlearned. The idea that 'a man is better served with a good housekeeper and educator of his children than with a walking library,' was commonly held. ${ }^{15}$

The debate on intellectual equality was intertwined with the issue of coeducation. The strict separation of the sexes was a bone of contention throughout the century. It was not only the church that frowned upon such a move. Even those who opposed the idea of intellectual inferiority of women, did not automatically accept a coeducational system. Girls were considered not weaker intellectually, but different, and for this reason they must be treated differently. ${ }^{16}$ Gottsched's proposal of a girl's university education was rejected on the grounds of girls having little physical stamina. Not even Campe accepted absolute equality of the sexes. ${ }^{17}$ In his view, the differences between the sexes intellectually and physically were not innate but resulted from the different educational pattern which they followed. The arguments pro and contra, though strenuously advocated, did not in the end bring about any significant change. In spite of these non-traditional, partly progressive proposals, reality remained stagnant. No-one gave practical advice or indicated a means to alleviate the problem. In one of the 'Weeklies' a young lady complained vigorously about her own anemic education, which 'not only she had received but most of her sex. ${ }^{\prime} 18$

With Basedow a fresh idea entered the discussion. He advocated a woman's professional training in case marriage did not materialize, so that her economic independence would be secured. However, in the final analysis his attitude remained ambiguous. He was convinced that a woman would not easily leave her state of dependence, which meant, she had to be taught to be submissive. ${ }^{19}$ Although in general, the philanthropists were more male-oriented in their theories of education, they pursued two remarkable aims with regard to girls:

1 a secondary education which went beyond the boundaries of rudimentary knowledge and 
2 the extension of this type of schooling to the middle class, where in the Christian economy the ideals of housewifely virtues were still epitomized.

The founders of girls' institutions among the philanthropists, advanced a new educational purpose: attainment of the ability to enjoy one's freedom, which would provide the individual with the necessary prerequisites to exchange her state of dependence for independence. This goal would lead to the possibility of engaging in a profession. Most institutions for girls' secondary education, however, were imitations of French models and only of short duration. ${ }^{20}$

In the wake of the French Revolution, the claim for institutionalization and nationalization of schools became stronger in the enlightened absolutist state, especially the question of secondary education for all classes and both sexes. ${ }^{21}$ The growing demand for institutionalized education resulted in proposals of pedagogical training for future women teachers.

But by the close of the century the 'lack of culture' ('Unkultur') together with existing educational practice as regards women were identified as an incurable disease of society, 'a devouring cancer which gnaws at the body of every state. ${ }^{\prime 22} \mathrm{~A}$ woman was now permitted to enter university, to engage in practical and charitable activities. The question remains, whether this was a liberation from tutelage as Kant had demanded? The answer is affirmative to a limited degree.

Emancipation was never demanded explicitly by women. If the system in power was criticized, it was attacked by men, never by women. If women tried to evade their normal duties as housewives, their actions were not only condemned by men but also by other women. The ideas of women's education which were propagated throughout the century were meant to erase social barriers and the pedagogical separation of the sexes. But in the course of history there were still some hurdles to overcome to make a woman independent of the limitations of her sex.

The educational theorists of the eighteenth century may have modernized without abandoning traditional attitudes in the populace and among themselves. When at the turn of the century institutionalized girls' schools for the upper as well as the lower classes were demanded, marriage was still considered a woman's goal in life. In most cases, this was not even a love marriage and hence required self-denial. It meant that a woman's activities, including her exiguous education, were subordinated to the purpose of marriage. The education proposed fitted her exactly for the role she was expected to fulfil in life: spending her time at home, running the household and rearing the children. ${ }^{23}$ 
But a girl also knew that if she did not get married, her future would be jeopardized and probably deplorable.

Analyzing women's education, one must not forget that the majority of women remained content with their roles and served without complaint. The coming of age rested upon intellectual as well as economic independence and that was not achieved in the eighteenth century. However, its gains enabled a woman to rise as an individual approaching one step closer to equality.

\section{CHRISTA FELL \\ Queen's University}

\section{Notes}

1 This topic requires a much fuller treatment than can be given here. But there would seem to be some merit in presenting generalizations in English about the trend under discussion. I also would like to draw the reader's attention to an excellent study which includes a detailed bibliography on the subject: Ulrich Herrmann, 'Erziehung und Schulunterricht für Mädchen im 18. Jahrhundert,' in Wolfenbütteler Studien zur Aufklärung, vol. III (Bremen/Wolfenbüttel: Jacobi, 1976), pp. 101-127.

2 Dietrich Veit, Eine kurtze Vermanung an die Eheleut (1548), Quellen und Forschungen zur Erbauungsliteratur des späten Mittelalters und der frühen Neuzeit, ed. A.v. D. Lee et al. (Assen: van Gorcum, 1972), V, 130.

3 Christoph Ott (Jesuit 1612-84), Hohe Schul der lieben Eltern. Gedruckt zu Ingolstadt in der Ederischen Truckerey, 1657, p. 372. Signatur HAB 758.12 Th 80 (4).

4 Juan Luis Vives (1492-1556), De instructione Faeminae Christianae (Antverpiae apud Michaelem Hillenium Hoochstratanum 1523. German: Christopher Bruno, Von underweysung ayner Christlichen Frauwen. Augsburg: Stainer, 1544), preface. Signatur HAB QuH22 (4).

5 The German reads as follows: 'Nun bist Du getäufft/drum gleich darauff ersäufft.' Die Neue böse Post ... durch öffentlichen Druck hiermit überlassen worden von Nicolao Höpffnern, Pfarrern zu Draschwitz bey Zeitz/und des Naumburgischen Stiffts, Ministerri Seniorn (Jena Verlegts Johann Bielcke/BuchHändler, 1700), preface.

6 Manfred O. Fleischer, 'Are Women Human?: The debate of 1595 between Valeus Aciladius and Simon Gedicus,' The Sixteenth Century Journal 12, 2 (1981), 107-20. In the 17th century, Grund = und probierliche Beschreibung ... Belangend die Frag / Ob die Weiber Menschen seyn / oder nicht, 1617, printed 
1660 - Johannes Nicolaus Pfizer in his gynecological handbook, Zwey sonderbare Bücher / von der Weiber Natur (Nürnberg / In Verlegung Johann Andreae und Wolfgang Endters desz Jüngeren / (1673) argued inconclusively that, since all male animals have a female counterpart, the same must be true for human males.

7 J.G. Kayßlers Reisen (Hannover, 1751), vol II, p. 1414.

8 Veit Ludwig von Seckendorff, Christen-Stat, (Leipzig, 1693), pp. $601 \mathrm{ff}$.

9 Dorothea von Erxleben, née Leporin, received her doctorate in medicine.

10 Wilhelm Ignatius Schütz, Ehrenpreis des lieb-löblichen weiblichen Geschlechtes (Frankfurt a.M., 1673).

11 Georg Christian Lehms, Teutschlands galante Poetinnen (Frankfurt/M, 1715), especially p. 63.

12 'Der Patriot,' II, $145 \mathrm{ff}$.

13 'Die Vernünftigen Tadlerinnen,' Andrer Jahr-Theil, 1726 (Leipzig: Bey Johann Friedrich Brauns, sel. Erben, 1727), p. 344.

14 'Die Vernünftigen Tadlerinnen,' 2nd ed., Stück 29, 1738; also Justus Möser, Patriotische Phantasien, vol. I, 1778, p. 120 ('die gute selige Frau').

15 'Die Zellischen Vernünftigen Tadlerinnen,' 29. Stück.

16 Friedrich Heinrich Christian Schwarz, Grundriß einer Theorie der Mädchenerziehung in Hinsicht auf die mittleren Stände (Jena, 1792), pp. $221 \mathrm{ff}$.

17 Johann Heinrich Campe, Väterlicher Rath für meine Tochter. Ein Gegenstück zum Theoptron, der erwachsenen weiblichen Jugend gewidmet 2. Aufl. (Tübingen, 1789), p. 5 .

18 'Wochenschrift zum Besten der Erziehung der Jugend,' II, 36.

19 Johann Bernhard Basedow, Das Methodenbuch für Väter und Mütter der Familien und Völker (Bremen, 1770).

20 e.g. École des demoiselles des Herzogs Karl Eugen von Württemberg in Stuttgart (model: St. Cyr); an institution in Frankenthal, established by Mme Lequier for young protestant girls; the 'Frauenzimmer-Erziehungsanstalt' in Straßburg.

21 The philanthroposophists Stuve, Stephani, and Pestalozzi were great promoters of these ideas. The contemporary paedagogical literature flourished, e.g., Johann Heinrich Campe, Väterlicher Rat für meine Tochter (Braunschweig, 1789); Theodor Gottlieb von Hippel, über die bürgerliche Verbesserung der Weiber (Berlin: Voß, 1792); über die Ehe (particularly chapter V [1793]); HP1. über weibliche Bildung; Friedrich Heinrich Christian Schwarz, Grundriß einer Theorie der Mädchenerziehung in Hinsicht auf die mittleren Stände (Jena: Cröker, 1792) was published in several editions; August Hermann Niemeyer, Grundsätze der Erziehung und des Unterrichts für Eltern, Hauslehrer und Erzieher, 3 vols. (Halle, 1796); Christian Friedrich Weiße translates F. Burton's lectures into German: Vorlesungen über weibliche Erziehung und Sitten, 2 vols. (Leipzig: Gräff, 1795); Jean Paul Richter, Levana oder Erziehlehre (Braunschweig, 1806); Caroline Rudolphi, Gemälde weiblicher Erziehung (Heidelberg, 1807).

22 Voß, Versuch einer Erziehung für den Staat (Halle, 1799), vol. I, 427.

23 The five printings of J.L. Ewald, Die Kunst ein gutes Mädchen eine gute Gattin, Mutter und Hausfrau zu werden (1st, ed., 1789; 5th ed., 1826) testify to the truth of this claim. 